\title{
Purification and Characterization of an Anti-cancer Enzyme Produced by Marine Vibrio Costicola Under A Novel Solid State Fermentation Process
}

\author{
G. Nagendra Prabhu* and M. Chandrasekaran \\ Microbial Technology Unit, Department of Biotechnology, Cochin University of Science \& Technology, Cochin - \\ 682 022, India; *Present address: P. G. Department of Zoology \& Research Centre, S.D. College, University of \\ Kerala, Alleppey - 688 003, India
}

\begin{abstract}
L - Glutaminase, a therapeutically and industrially important enzyme, was produced from marine Vibrio costicola by a novel solid state fermentation process using polystyrene beads as inert support. The new fermentation system offered several advantages over the conventional systems, such as the yield of leachate with minimum viscosity and high specific activity for the target product besides facilitating the easy estimation of biomass. The enzyme thus produced was purified and characterised. It was active at physiological $\mathrm{pH}$, showed high substrate specificity towards $L$ - glutamine and had a Km value of $7.4 \times 10^{-2} \mathrm{M}$. It also exhibited high salt and temperature tolerance indicating good scope for its industrial and therapeutic applications.
\end{abstract}

Key words: L- Glutaminase, Vibrio costicola, solid state fermentation, inert support, purification and characterisation

\section{INTRODUCTION}

L-Glutaminase (L-glutamine amidohydrolase EC 3. 5. 1. 2) is recognised for its use as a potent antileukaemic agent (Roberts et al, 1970; Pal \& Maity, 1992) and as a flavour-enhancing agent of fermented foods (Yokotsuka, 1985). Since the enzyme from different sources differ greatly in their properties such as anticancer activity, immunogenicity, cytotoxicity, activity at physiological conditions, plasma clearance rate, substrate specificity, temperature, $\mathrm{pH}$ and salt tolerance etc., there is a continuous search for L- glutaminase with properties suitable for its use as antileukaemic and/or flavourenhancing agent. Its therapeutic and industrial importance demands not only the search for new and better yielding microbial strains but also economically viable bioprocesses for its large scale production (Nagendra Prabhu \& Chandrasekaran, 1996).

Solid state fermentation (SSF), which is the culturing of micro-organisms on moist solid supports in the absence of free-water, is a promising biotechnology for the production of useful microbial enzymes, antibiotics, organic acids, food flavours, alkaloids and other bioactive secondary metabolites (Pandey, 1992; Lonsane, 1994). The success of SSF processes greatly depend on the type of the microorganism and the substrate used. Marine microorganisms are reported to be highly suitable for use in SSF because of their salt tolerance, ability to produce novel metabolites and the capacity to adsorb onto the solid particles (Chandrasekaran, 1996 \& 1997). Similarly, use of nutritionally inert supports have been recommended in SSF, in-order to overcome the inherent drawbacks of the conventional SSF systems using nutrient-rich substrates such as wheat bran (Aidoo et al, 1982; Nagendra Prabhu \& Chandrasekaran, 1995). Recently we have developed a new SSF system based on a nutritionally inert material, polystyrene [Poly(1-phenylethylene)], for Lglutaminase production by marine Vibrio costicola (Nagendra Prabhu \& Chandrasekaran, $1995 \& 1997)$.

\footnotetext{
* Author for correspondence
} 
This paper deals with the purification and characterisation of L-glutaminase produced by marine Vibrio costicola under SSF using polystyrene beads as inert support.

\section{MATERIALS AND METHODS}

Micro-organism and solid state fermentation: Vibrio costicola ACMR 267 isolated from the marine environment of Cochin, Kerala, India, and maintained on ZoBell's marine agar slants, was used (Renu \& Chandrasekaran, 1992). Enzyme production under SSF using polystyrene beads was carried out according to a new protocol developed by the authors. $5 \mathrm{gm}$ of polystyrene beads, taken in $250 \mathrm{ml}$ Erlenmeyer flasks were moistened with $5 \mathrm{ml}$ of aged sea water media containing Lglutamine $(2 \% \mathrm{w} / \mathrm{w})$, maltose $(1 \% \mathrm{w} / \mathrm{w})$ and $\mathrm{KH}_{2} \mathrm{PO}_{4}(1 \% \mathrm{w} / \mathrm{w})$. After sterilisation, the flasks were inoculated with $2 \mathrm{ml}$ of inoculum $(0.750 \mathrm{mg}$ dry wt $/ 10 \mathrm{gm}$ substrate $)$ and incubated at $35^{\circ} \mathrm{C}$ for $24 \mathrm{~h}$ under $75-80 \%$ relative humidity. L-Glutaminase was extracted using phosphate buffer $(0.1 \mathrm{M}, \mathrm{pH} 7.0,1: 5 \mathrm{w} / \mathrm{v}$ per flask). After extracting twice, the extracts were pooled, centrifuged at $10000 \mathrm{rpm}$ for 30 min at $4^{\circ} \mathrm{C}$ and the supernatant was used as the crude enzyme (Nagendra Prabhu \& Chandrasekaran, 1995, 1997).

Enzyme purification: L-Glutaminase was purified by ammonium sulphate fractionation followed by dialysis and gel-filtration chromatography. Ammonium sulphate fractionation was carried out at $4^{\circ} \mathrm{C}$ in an ice bath. The precipitated protein was collected by centrifugation at $10000 \mathrm{rpm}$ at $4^{\circ} \mathrm{C}$ and dissolved in a minimum volume of phosphate buffer $(0.01 \mathrm{M}, \mathrm{pH} 8.0)$. Fractions obtained in the range of $50-80 \%$ saturation of ammonium sulphate were pooled and dialysed against the same buffer for $24 \mathrm{~h}$ at $4^{\circ} \mathrm{C}$ with continuous stirring and occasional changes of the buffer. The dialysate was concentrated by lyophilization and applied on top of a gelfiltration column $(1.5 \times 50-\mathrm{cm})$ containing Sephadex G 100. Elution was carried out in a cold room using phosphate buffer $(0.1 \mathrm{M}, \mathrm{pH}$ 8.0) containing $0.1 \mathrm{M} \mathrm{NaCl}$ and $0.001 \mathrm{M}$ EDTA.
Fractions of $2.5 \mathrm{ml}$ were collected at a flow rate of $50 \mathrm{ml} / \mathrm{h}$. Each fraction was analysed for protein and glutaminase. Active fractions were pooled and concentrated by lyophilization (Nagendra Prabhu, 1997). Purity was confirmed by polyacrylamide gel electrophoresis under denaturing and non-denaturing conditions (Hames, 1990)

Analytical techniques: Protein was estimated by Lowry's method (Lowry et al, 1951) or by measuring absorbance at $280 \mathrm{~nm}$. LGlutaminase was assayed according to Imada $e t$ al (1971). One international unit of glutaminase was defined as the amount of enzyme that liberates $1 \mu \mathrm{mol}$ of ammonia under optimal assay conditions. Enzyme yield was expressed as Units/gm dry substrate (U/gds). Viscosity of the leachate (extractant) was measured using Ostwald viscometer and expressed as Newtons $/ \mathrm{m}^{2}\left(\mathrm{Ns} / \mathrm{m}^{2}\right)$.

Enzyme characteristics: The purified glutaminase was characterised for its various properties. The characters analysed included effect of $\mathrm{pH}(4-10)$ and temperature (30 $80^{\circ} \mathrm{C}$ ) on enzyme activity and stability, effect of $\mathrm{NaCl}(0-20 \%)$ on enzyme activity, effect of substrate concentration (L - glutamine; 0.01 $1.0 \mathrm{M})$ on enzyme activity, effect of Lglutamine $(0.01 \mathrm{M})$ and $\mathrm{NaCl}(10 \%)$ on temperature stability of glutaminase and the substrate specificity the enzyme (Nagendra Prabhu, 1997).

\section{RESULTS AND DISCUSSION}

Enzyme production: Vibrio costicola produced extra-cellular L-glutaminase under SSF using polystyrene as inert support. The nutritionally inert polystyrene beads provided surface for the attachment of bacteria during fermentation. Under optimised conditions, a maximum glutaminase yield of $232 \mathrm{U} / \mathrm{gds}$ was obtained, which was the second highest enzyme yield reported for L-glutaminase (Nagendra Prabhu \& Chandra-sekaran, 1997). The new SSF system offered several advantages over the conventional systems using nutrient-rich substrates such as wheat bran. The leachate obtained from the polystyrene SSF system was 
less viscous $\left(0.966 \mathrm{Ns} / \mathrm{m}^{2}\right)$, showed high specific activity for glutaminase $(4.2 \mathrm{U} / \mathrm{mg}$ protein) and was free of undesired proteins. Whereas the leachate from wheat bran was highly viscous $\left(2.072 \mathrm{Ns} / \mathrm{m}^{2}\right)$ and contained amylase and cellulase in addition to glutaminase. (Nagendra Prabhu \& Chandrasekaran, 1995, 1997). These features are highly beneficial for the enzyme industry since this may eliminate the problems associated with the viscous nature of the leachate from natural substrates (Ramesh \& Lonsane, 1989). Furthermore, 92-96\% of the leachate could be recovered from the polystyrene system compared to the wheat bran system from which only $82-85 \%$ recovery is normally possible. The other major advantage of the new SSF system is the ability to measure biomass easily and accurately, which is difficult with conventional SSF systems (Nagendra Prabhu \& Chandrasekaran, 1995, 1996, 1997). These factors may have good application in the scaling-up studies and the development of an ideal SSF system using both nutrient-rich and inert substrates.

Enzyme purification: L-Glutaminase was purified to homogeneity after successive steps of purification. The crude extract contained 428 $\mathrm{mg}$ of protein and showed a total glutaminase activity of 5846 units with a specific activity of 13.66 U/mg protein. After purification, the specific activity increased to $596.67 \mathrm{U} / \mathrm{mg}$ protein with a yield of $30.62 \%$. The details of purification steps are given in Table-1. Electrophoretic studies showed a subunit molecular weight of 36,000 daltons and that of native protein was found to be 144,000 daltons (Nagendra Prabhu, 1997). Bacterial amidohydrolases are reported to be homotetramers of identical subunits and the individual subunits are not catalytically active. The molecular weight was reported to range from 120,000 to 147,000 daltons (Ammon et al, 1988).

Table 1: Purification of L-Glutaminase

\begin{tabular}{lrrrl}
\hline $\begin{array}{l}\text { Purif. } \\
\text { Step }\end{array} \begin{array}{l}\text { Protein } \\
(\mathrm{mg} / \mathrm{ml})\end{array}$ & $\begin{array}{c}\text { Activity } \\
(\mathrm{U})\end{array}$ & $\begin{array}{c}\text { Sp.act. } \\
\mathrm{U} / \mathrm{mg}\end{array}$ & $\begin{array}{c}\text { Yield } \\
(\%)\end{array}$ & $\begin{array}{l}\text { Fold } \\
\text { purif. }\end{array}$ \\
\hline $\begin{array}{l}\text { Crude } 428 \\
\text { Extract }\end{array}$ & 5846 & 13.66 & 100 & 1.00 \\
$\begin{array}{l}\text { Am. Sul. 127 } \\
\begin{array}{l}\text { Fraction } \\
\text { Gel- }\end{array}\end{array}$ & 3572 & 28.13 & 61.10 & 2.06 \\
Filtration & 1790 & 596.67 & 30.62 & 43.68 \\
\hline
\end{tabular}

Enzyme characteristics: The enzyme was active over a range of $\mathrm{pH}$ 6-9 with optimum at pH $8.0 \quad$ (Fig.1). The activity considerably decreased at both low $\mathrm{pH}$ (5.0) and high $\mathrm{pH}$ (10.0). The $\mathrm{pH}$ stability of the enzyme also showed a similar trend, the enzyme being most stable at $\mathrm{pH}$ 8.0.

Results presented in Fig. 2 suggested that glutaminase from $V$. costicola preferred $40^{\circ} \mathrm{C}$ as its optimum temperature. However, it retained $85 \%$ of the activity over a temperature range of $25-45^{\circ} \mathrm{C}$ and was stable up to $45^{\circ} \mathrm{C}$.

Figure 1: Effect of $\mathrm{pH}$ on activity and stability

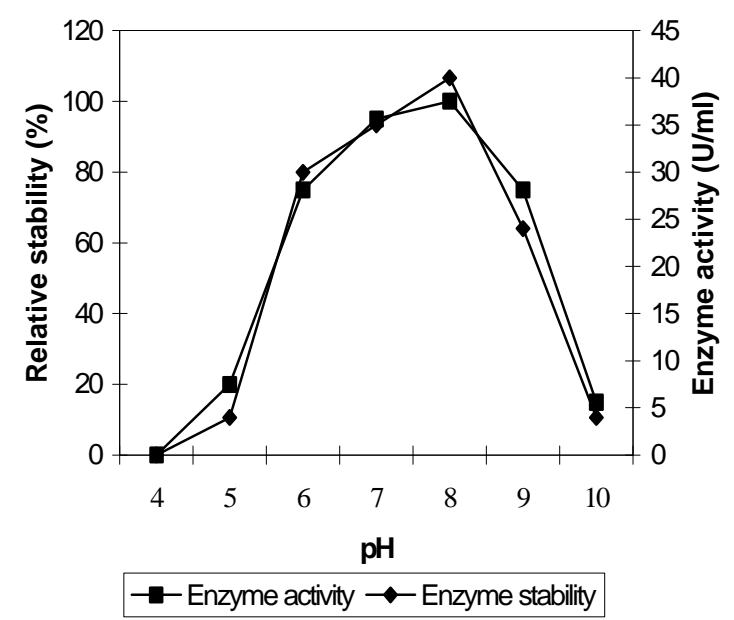

Figure 2: Effect of temperature on activity and stability.

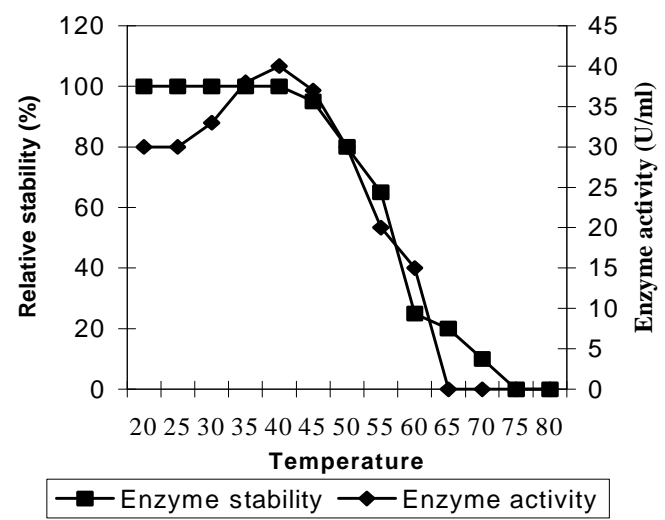


In presence of substrate (L- glutamine) or $\mathrm{NaCl}$, the thermostability of the enzyme increased upto $55^{\circ} \mathrm{C}$. About $76-82 \%$ of activity was retained at $60^{\circ} \mathrm{C}$ in presence of $0.01 \mathrm{M} \mathrm{L}$ glutamine or $10 \% \mathrm{NaCl}$ (Fig.3). Data presented in Fig.4 indicate the salt tolerant nature of glutaminase from marine $V$. costicola. It retained $90 \%$ of activity at $10 \% \mathrm{NaCl}$ concentration and $75 \%$ activity upto $15 \% \mathrm{NaCl}$, compared to the glutaminase - I from marine Micrococcus sp. which recorded $100 \%$

Figure 3: Effect of L-Glutamine and $\mathrm{NaCl}$ on temperature stability.

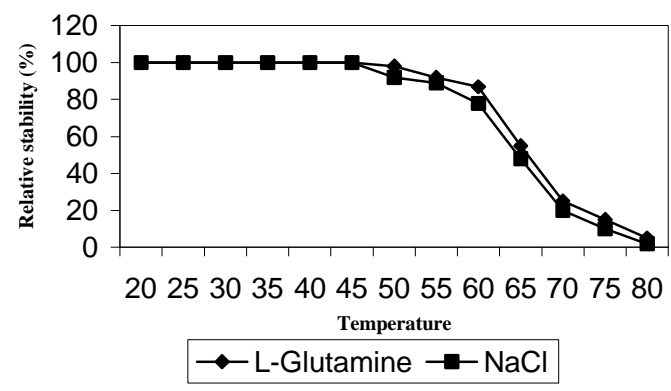

Figure 4: Effect of $\mathrm{NaCl}$ on glutaminase activity.

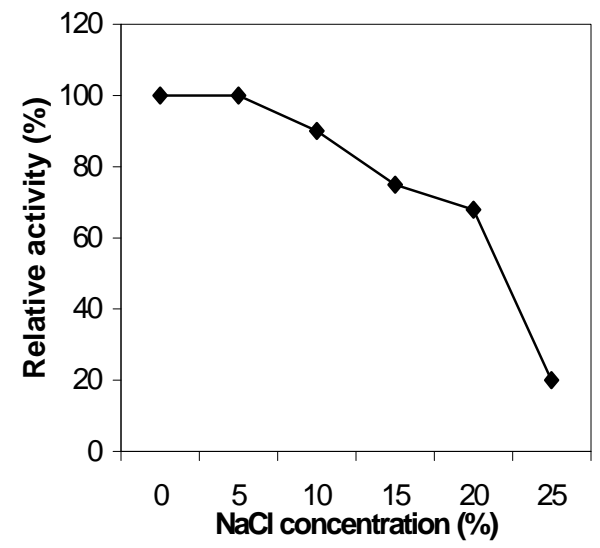

Figure 5: Substrate specificity of glutaminase

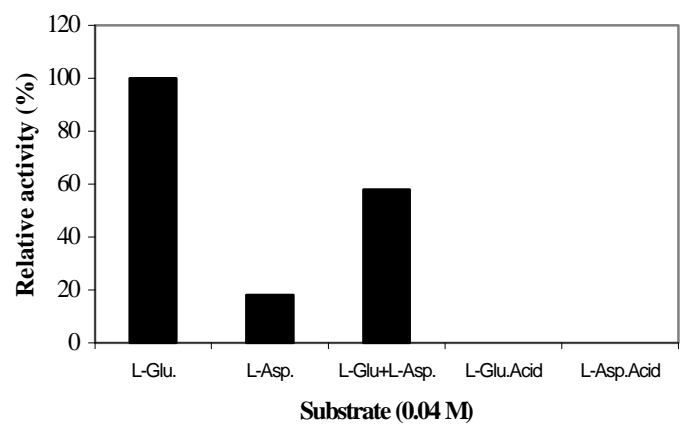

activity at $10-16 \% \mathrm{NaCl}$ (Moriguchi et al, 1994). Whereas glutaminase from non-marine microbes were found to be inactivated at high salt concentrations, limiting their industrial potential. A substrate concentration of $0.04 \mathrm{M}$ was found to be optimum and the $\mathrm{Km}$ value was calculated to be $7.4 \times 10^{-2}$ (data not shown). Further the enzyme showed high specificity for L-glutamine, very low specificity towards L asparagine and no activity with aspartic acid and glutamic acid (Fig.5). This feature increases its potential for use as an anticancer agent.

\section{CONCLUSIONS}

The L-glutaminase produced by the organism has several beneficial properties needed for a therapeutic and industrial enzyme. It is active and stable over a wide range of $\mathrm{pH}$ and temperature and in highly salt-tolerant. The substrate specificity towards L-glutamine is also very high which means that it could be used in low amounts to achieve the desired effect. Preliminary studies indicated that the purified glutaminase was a potential therapeutic agent in the treatment of cancer (unpublished data). Based on the results obtained in the present study, we conclude that the marine Vibrio costicola has immense potential for large scale production of L-glutaminase having several beneficial properties for its use as an anticancer agent and in the food industry.

Acknowledgement: GNP is grateful to the Council of Scientific \& Industrial Research, Government of India for a Research Fellowship. 


\section{RESUMO}

O L - Glutaminase, uma enzima terapêutica industrialmente importante foi produzida a partir do Vibrio costicola marinho. Por um processo de fermentação no estado sólido, em particular contas de poliestireno foram utilizadas como suporte inerte. O novo sistema de fermentação ofereceu várias vantagens sobre os sistemas convencionais, como rendimento de "leachate" com viscosidade mínima e atividade específica alta para o produto; facilidade a estimação da biomassa. A enzima assim produzida foi purificada e caracterizada. A enzima apresentou atividade elevada em $\mathrm{pH}$ fisiológico e alta especificidade ao substrato em direção a $\mathrm{L}$ - glutamina com um valor $\mathrm{Km}$ de $7.4 \times 10^{-2} \mathrm{M}$. A enzima também exibiu alta tolerância ao sal e temperatura demonstrando ser um bom indicador para aplicações terapêuticas e industriais.

\section{REFERENCES}

Aidoo, K.E. Hendry, R. \& Wood, B.J.B. (1982), Solid state fermentations. Adv. Appl. Micro. 28, 201-237

Ammon, H.L, Weber, I.T, Wlodawer, A. Harrison, R.W, Gilliland, G.L, Murphy, K.C, Sjolin, L \& Roberts, J. (1988), Preliminary crystal structure of Acinetobacter glutaminasificans glutaminase-asparaginase. J. Biol. Chem. 263, 150-156

Chandrasekaran, M. (1996), Harnessing marine microorganisms through solid state fermentation. J. Sci. Ind. Res. 55, 468-471

Chandrasekaran, M. (1997), Industrial enzymes from marine microorganisms: the Indian scenario. J. Mar. Biotech. 5, 86-89

Hames, B.D in Gel electrophoresis - a practical approach (ed) B.D. Hames \& D. Rickwood, (IRL Press, Oxford) $1990 \mathrm{pp}$ 1-47

Imada, A, Igarasi, S, Nakahama, K \& Isono, M. (1973), Asparaginase and glutaminase activities of microorganisms. J. Gen. Micro. 76, 85-99.

Lonsane, B.K. (1994), Resurgence of interest in solid state fermentation: Reasons and justifications. In- Solid state fermentation, ed A. Pandey, Wiley Eastern Ltd, New Delhi, pp 11-20

Lowry, O.H, Rosebrough, N.N., Farr, A.L \& Randall, R.Y. (1951), Protein measurement with the folin phenol reagent. J. Biol. Chem. 193, 265-275

Moriguchi, M, Sakai, K, Tateyama, R, Furuta, Y \& Wakayama., M (1994), Isolation and characterisation of salt tolerant glutaminase from marine Micrococcus luteus K-3. J. Ferm. \& Bioeng. 77, 621-625

Nagendra Prabhu, G \& Chandrasekaran, M. (1995), Polystyrene: an inert carrier for Lglutaminase production by marine Vibrio costicola under solid state fermentation. World J. Microbiol. Biotechnol., 11, 683 684

Nagendra Prabhu, G \& Chandrasekaran, M. (1996), L-Glutaminase production by marine Vibrio costicola under solid state fermentation using different substrates. $J$. Mar. Biotech.. 4, 176-179

Nagendra Prabhu, G \& Chandrasekaran, M. (1997), Impact of process parameters on Lglutaminase production by marine Vibrio costicola in solid state fermentation using polystyrene as an inert support. Process Biochem., 32, 285-289

Nagendra Prabhu, G. (1997), L-Glutaminase production by marine Vibrio costicola under solid state fermentation. Ph.D. Thesis, Cochin University of Science \& Technology, Cochin, India

Pal, S \& Maity, P. (1992), Antineoplastic activities of purified bacterial glutaminase on transplanted tumour systems. Indian J. Cancer Chemother. 13, 73-76

Pandey, A. (1992), Recent process developments in solid state fermentations. Proc. Biochem.. 27, 109-117.

Ramesh, M.V \& Lonsane, B.K. (1989),Purification of thermostable alpha amylase produced by Bacillus licheniformis M 27 under solid state fermentation. Proc. Biochem.. 24, 176-178

Renu, S \& Chandrasekaran, M. (1992), Extracellular L-glutaminase production by marine bacteria. Biotech. Lett.. 14, 471-474.

Roberts, J, Holcenberg, J.S \& Dolowy, S.C. (1970), Antineoplastic activity of highly purified bacterial glutaminase. Nature, 227, 1136- 1137

Yokotsuka T. (1985), Fermented protein foods in the Orient, with emphasis on shoy and miso in Japan. In-Microbiology of fermented foods, ed B.J.B. Wood Elsevier Applied Science, London, pp 197-247

Received August 30, 1999; Revised September 21, 1999; Accepted September 28, 1999. 